\title{
HUBUNGAN KESIAPAN GURU TERHADAP PERUBAHAN KURIKULUM 2013 PADA TINGKAT KEAKTIFAN SISWA DI SMA MUHAMMADIYAH 3 JEMBER DAN SMA NEGERI 2 TANGGUL
}

\author{
Dinda Ayu Pramesty ${ }^{1}$, Anik Nur Khasanah ${ }^{2}$, Erika Yulinda ${ }^{3}$, Nur Lailatul Khomariyah ${ }^{4}$, \\ M. Zam-Zam Ali Saga ${ }^{5}$, Giffari Ibnu Hisyam ${ }^{6}$ \\ Pendidikan Geografi, Universitas Jember, Indonesia \\ e-mail: dindayupramesty25@gmail.com
}

\begin{abstract}
This study aims to determine the readiness of teachers for changes in the 2013 curriculum at the level of student activity in SMA Muhammadiyah 3 Jember and SMA Negeri 2 Tanggul. As for the background of this research is the relationship of curriculum change to the 2013 curriculum to the readiness of teachers in the two schools which serve as benchmarks for student activity. The method used is observational research. Data collection techniques are done using interviews and documentation. Data analysis techniques were performed using descriptive analysis techniques. The results of this study are that there are differences of opinion between teachers in SMA Muhammadiyah 3 Jember and SMA Negeri 2 Tanggul obtained from a questionnaire distribution distributed to teachers and students in the two schools.
\end{abstract}

Keywords: Student Activity, Teacher Readiness, Curriculum Change

\begin{abstract}
Abstrak: Penelitian ini bertujuan untuk mengetahui kesiapan guru terhadap perubahan kurikulum 2013 pada tingkat keaktifan siswa di SMA Muhammadiyah 3 Jember dan SMA Negeri 2 Tanggul. Adapun yang menjadi latar belakang penelitian ini adalah hubungan perubahan kurikulum menjadi kurikulum 2013 terhadap kesiapan guru yang ada di kedua sekolah tersebut yang menjadi tolak ukur keaktifan siswa. Metode yang digunakan adalah penelitian observasi. Teknik pengumpulan data dilakukan menggunakan metode wawancara dan dokumentasi. Teknik analisis data dilakukan dengan menggunakan teknik analisis deskriptif. Hasil dari penelitian ini yaitu terdapat perbedaan pendapat antara guru di SMA Muhammadiyah 3 Jember dan SMA Negeri 2 Tanggul yang didapat dari distribusi angket yang disebarkan kepada guru dan siswa di kedua sekolah tersebut.
\end{abstract}

Kata Kunci: Keaktifan Siswa, Kesiapan Guru, Perubahan Kurikulum

\section{PENDAHULUAN}

Pendidikan merupakan hal yang sangat penting bagi setiap negara yang ada, dengan tujuan agar negara dapat berkembang dengan baik dan dapat mewujudkan negara yang makmur. Pendidikan menjadi sebuah prioritas utama bagi setiap negara, dimana dengan pendidikan yang dapat berjalan dengan baik, maka permasalahan sosial seperti kesejahteraan masyarakatnya dapat diimbangi dan dapat diminimalisisr dengan kesejahteraan masyarakat. Dalam pendidikan terdapat unsur penting yang mampu dalam mengarahkan potensi potensi yang dimiliki oleh peserta didik yaitu kurikulum. Kurikulum merupakan alat pembelajaran di pendidikan guna sebagai rencana, yang berkaitan dengan mata pembelajaran dan tingkatan perkelas dan berkembang sesuai zaman, kurikulum juga dapat digambarkan sebagai suatu rencana dalam tindakan ataupun dokumen tertulis yang melipusi strategi untuk mencapai tujuan supaya berjalan lancar (Tatang, 2011). Kurikulum juga dapat didefinisikan dengan seperangkat mata pelajaran dan pendidikan yang di berikan dari suatu lembaga penyelenggara pendidikan yang diberikan kepada peserta didik pada periode tertentu.

Pergantian atau perkembangan kurikulum dari tahun ke tahun tidaklah lepas dari beberapa permasalahan dalam mengimplementasikan kurikulum baru pada dunia pendidikan. 
Indonesia telah melakukan beberapa kali perubahan atau pembaruan pada kurikulum guna untuk meningkatkan kualitas sumber daya manusianya melalui pembelajaran. Dalam kaitan ini kurikulum tingkat satuan pendidikan (KTSP) dan kurikulum 2013 pun menjadi pusar perhatian dan menimbulkan pemikiran pemikiran baru sehingga mengalami perubahan (Gunawan, 2017). Perubahan atau pengembangan kurikulum terjadi pada Kurikulum Tingkat Satuan Pendidikan (KTSP) yang berkembang menjadi Kurikulum 2013 dengan maksud dapat menghasilkan sumber daya manusia di Indonesia yang lebih produktif, afektif, inovasi, dan kreatif melalu pembelajaran sikap, keterampilan dan pengetahuan yang telah dirancang. Akan tetapi dalam penerapan K13 terdapat beberapa permasalahan yang dihadapi yaitu permasalahan yang muncul dari arah input, proses, hingga output. Salah satu contoh permasalahan yang terjadi yaitu kesiapan guru dalam menerapkan model pembelajaran atau metode pembelajaran pada kurikulum yang lebih mengarah ke IPTEK dimana banyak guru yang merasa terbebani dengan itu, dikarenakan masih banyak guru senior yang tidak terlalu paham mengenai IPTEK, selain guru peserta didik juga mengalami kesulitan dalam mengikuti perkembangan kurikulum ini.

Hasil penelitian terdahulu yang telah dilakukan oleh Afandi, R. (2013) mengenai Implementasi Kurikulum 2013 Dalam Mempersiapkan Sumber Daya Manusia Indonesia Menghadapi "Masyarakat Ekonomi Asean" (Asean Economic Community) Pada 2015, menunjukan bahwa terdapat beberapa permasalahan yang ada dalam pengimplementasian Kurikulum 2013, permasalahan permasalahan yang ada antara lain yaitu terletak pada buku guru dan buku siswa kurikulum 2013, pelatihan terhadap guru yang belum maksimal, sarana dan prasarana belum mendukung proses belajar mengajar dalam implementasi kurikulum 2013, guru mengalami kesulitan mengajar TIK. Berdasarkan hasil penelitian yang telah dilakukan, menunjukan bahwa pengimplementasian Kurikulum 2013 masih belum maksimal, sehingga masih perlu di perbaiki lagi. Penelitiann lain yang juga membahas tentang implementasi kurikulum dilakukan oleh Wijayati (2016) memaparkan bahwa permasalahan yang dirasakan oleh guru tentang perubahan atau pengembangan kurikulum yaitu terletak pada kurangnya pemahaman dan keterampilan guru dalam pembuatan instrument penilaian dikarenakan saat ini guru masih belum terbiasa dalam melakukan berbagaimacam penilain.

Penelitian yang telah dilakukan sebelumnya tidak jauh berbeda dengan penelitian yang saat ini dilakukan. Kurikulum 2013 yang saat ini sudah di implementasikan hampir seluruh sekolah yang ada di Indonesia, memang memiliki beberapa kendala yang hampir sama terutama permasalahan pada penggunaan IPTEK. Berdasarkan penelitian yang telah dilakukan menarik peneliti untuk melakukan penelitian mengenai cara sekolah dalam pengimplementasikan Kurikulum 2013. Dengan tujuan agar peneliti tahu bagaimana cara sekolah sekolah yang ada di Jember dalam merealisasikan pengimplementasian Kurikulum 2013.

\section{METODE}

Metode penelitian yang digunakan merupakan penelitian observasi. Menurut Sutoyo (2009) memaparkan bahwa observasi dalam arti sempit memiliki pengertian sebagai pengamatan yang dilakukan secara langsung maupun tidak langsung terhadap gejala tertentu, sedangkan dalam arti luas observasi meliputi pengamatan yang dilakukan secara langsung maupun tidak langsung terhadap objek yang sedang diteliti. Lokasi penelitian dilakukan di SMA Muhammadiyah 3 Jember yang berada di Jl. Mastrip No.3, Lingkungan Panji, Tegalgede, Kec. Sumbersari, Kabupaten Jember, Jawa Timur dan di SMA Negeri 2 Tanggul yang berada Jl. Salak No.126, Krajan, Tanggul Wetan, Kec. Tanggul, Kabupaten Jember, Jawa Timur. Teknik pengumpulan data dilakukan menggunakan metode wawancara dan dokumentasi. Teknik analisis data dilakukan dengan menggunakan teknik analisis deskriptif. Penelitian yang menggunakan pada penelitian secara deskriptif berguna sebagai fungsi untuk memperoleh gambaran yang jelas, objektif, sistematis, dan cermat mengenai fakta-fakta aktual dari sifat populasi (Margono, 2015).

\section{HASIL DAN PEMBAHASAN}

Hasil distribusi angket dan wawancara di SMA Muhammadiyah 3 Jember dan SMA Negeri 2 Tanggul yaitu sebagai berikut: 
Tabel 1.1. Kuesioner Siswa di SMA Muhammadiyah 3 Jember dan SMA Negeri 2 Tanggul

\begin{tabular}{|c|c|c|c|c|c|c|c|}
\hline \multirow{2}{*}{ No } & \multirow{2}{*}{ Pertanyaan Siswa } & \multicolumn{3}{|c|}{ SMA Muhammadiyah 3 Jember } & \multicolumn{3}{|c|}{ SMA Negeri 2 Tanggul } \\
\hline & & Iya & Kadang & Tidak & Iya & Kadang & Tidak \\
\hline 1 & $\begin{array}{l}\text { Jika dari bebrapa hasil tes geografi, nilai yang } \\
\text { diperoleh ternyata kurang baik (belum mencapai KKM) } \\
\text { apakah siswa tetap bersemangat daam belajar? }\end{array}$ & 3 & 0 & 2 & 4 & 1 & - \\
\hline 2 & $\begin{array}{l}\text { Dalam menghadapi tes geografi apakah siswa } \\
\text { mempersiapkan diri dengan belajar tekun dan berlatih } \\
\text { soal soal? }\end{array}$ & 5 & 0 & 0 & 5 & - & - \\
\hline 3 & $\begin{array}{l}\text { Bila ada jadwal mata pelajaran geografi apakah kamu } \\
\text { membaca matapelajaran geografi yang akan } \\
\text { disampaikan besok? }\end{array}$ & 2 & 3 & 0 & 5 & - & - \\
\hline 4 & $\begin{array}{l}\text { Pada waktu luang atau jam jam kosong disekolah } \\
\text { apakah kamu memanfaatkan perustakaan guna } \\
\text { membaca buku buku terkait dengan mata pelajaran } \\
\text { geografi? }\end{array}$ & 1 & 1 & 3 & 3 & 0 & 2 \\
\hline 5 & $\begin{array}{l}\text { Apakah siswa berusaha untuk mempersiapkan materi } \\
\text { pelajaran dengan baik pada pelajaran geografi? }\end{array}$ & 1 & 3 & 1 & 3 & 1 & 1 \\
\hline 6 & $\begin{array}{l}\text { Apakah siswa berusaha secara serius dalam } \\
\text { menanggapi suatu permasalahan dalam tanya jawab } \\
\text { tentang soal soal geografi? }\end{array}$ & 3 & 2 & 0 & 4 & 0 & 1 \\
\hline 7 & $\begin{array}{l}\text { Apakah setiap kali ada kesulitan dalam mempelajari } \\
\text { pelajaran geografi apakah siswa pada diluar jam kelas } \\
\text { akan melakukan belajar kelompok unyuk belajar } \\
\text { geografi? }\end{array}$ & 0 & 4 & 1 & 4 & 0 & 1 \\
\hline 8 & $\begin{array}{l}\text { Apakah siswa berusaha mendapatkan nilai geografi } \\
\text { yang setinggi tingginya diantara teman tema satu kelas? }\end{array}$ & 1 & 1 & 3 & 5 & 0 & 0 \\
\hline 9 & $\begin{array}{l}\text { Apakah siswa mentargetkan nilai tes atau ulangan } \\
\text { pelajaran geografi yanglebih baik jika disbanding nilai } \\
\text { tes atau ulangan sebelumnya? }\end{array}$ & 5 & - & - & 5 & 0 & 0 \\
\hline 10 & $\begin{array}{l}\text { Apabila menemukan Soal geografi yang sulit untuk } \\
\text { dikerjakan apakah siswa berusaha mencari jawaban di } \\
\text { buku geografi lainnya? }\end{array}$ & 3 & 1 & 1 & 5 & 0 & 0 \\
\hline 11 & $\begin{array}{l}\text { Dalam mengerjakan tugas geografi apakah siswa } \\
\text { berusaha sebaik baiknya dalam menyelesaikan dengan } \\
\text { tepat waktu? }\end{array}$ & 5 & 0 & 0 & 5 & 0 & 0 \\
\hline 12 & $\begin{array}{l}\text { Apakah siswa dirumah mengulang materi yang } \\
\text { dipelajaridi sekolah? }\end{array}$ & 1 & 4 & 0 & 3 & 2 & 0 \\
\hline 13 & $\begin{array}{l}\text { Apakah siswa mempunyai trik atau cara belajar untuk } \\
\text { mempermudah dalam peningkatan belajar? }\end{array}$ & 1 & 4 & 0 & 3 & 2 & 0 \\
\hline 14 & $\begin{array}{l}\text { Apabila ada kesulitan dalam memcahkan masalah } \\
\text { apakah siswa akan melakukan diskusi bersama guru } \\
\text { geografi? }\end{array}$ & 3 & 2 & 0 & 4 & 1 & 0 \\
\hline 15 & $\begin{array}{l}\text { Apabila dalam KBM siswa tidak memahami dengan } \\
\text { penyampaian materi oleh guru maka siswa akan } \\
\text { menanyakan diluar jam kelas? }\end{array}$ & 1 & 3 & 1 & 3 & 2 & 0 \\
\hline 16 & $\begin{array}{l}\text { Apbila dalam mengerjakan ulangan atau tes geografi } \\
\text { apakah siswa berusaha untuk mengerjakannya dengan } \\
\text { kemampuan sendiri? }\end{array}$ & 2 & 3 & 0 & 4 & 1 & 0 \\
\hline 17 & $\begin{array}{l}\text { Apakah waktu belajar pelajaran geografi dirumah } \\
\text { selalu rutin terjadwal dengan baik? }\end{array}$ & 0 & 3 & 2 & 2 & 3 & 0 \\
\hline 18 & Apakah diwaktu KBM kodisi kelas kondusif? & 1 & 4 & 0 & 4 & 1 & 0 \\
\hline
\end{tabular}

Tabel 1.2. Distribusi Angket Guru di SMA Muhammadiyah 3 Jember dan SMA Negeri 2 Tanggul

\begin{tabular}{llllllll}
\hline \multirow{2}{*}{ No } & Angket Guru & \multicolumn{5}{l}{ SMA Muhammadiyah 3 Jember } & \multicolumn{3}{l}{ SMA Negeri 2 Tanggul } \\
\cline { 3 - 7 } & TS & S & SS & TS & S & SS \\
\hline 1 & $\begin{array}{l}\text { Apakah bapak/ibu setuju dengan perubahan kurikulum? } \\
\text { Apakah bapak/ibu setujudengan silabus yang dibuatkan } \\
\text { oleh pemerintah? }\end{array}$ & 6 & 7 & 1 & 1 & 9 & 0 \\
3 & $\begin{array}{l}\text { Apakah bapak/ibu setuju apabila semua mata pelajaran } \\
\text { diajarkan dengan pendekatan yang sama (santifik) } \\
\text { melalui mengamati, mencoba, menalar? }\end{array}$ & 5 & 3 & 2 & 3 & 5 & 2 \\
$\begin{array}{l}\text { Apakah bapak/ibu setuju dengan setiap mata pelajaran } \\
\text { mendukung semua kompetensi (sikap, keterampilan, } \\
\text { pengetahuan)? }\end{array}$ & 2 & 7 & 1 & 0 & 4 & 6 \\
\hline
\end{tabular}




\begin{tabular}{lllllll}
\hline \multirow{2}{*}{ No } & \multirow{2}{*}{ Angket Guru } & \multicolumn{3}{c}{ SMA Muhammadiyah 3 Jember } & \multicolumn{3}{c}{ SMA Negeri 2 Tanggul } \\
\cline { 3 - 7 } & & $T S$ & $S$ & $S S$ & $T S$ & $S$ \\
\hline 5 & Apakah hasil belajar siswa lebih baik dari k13? & 7 & 3 & 0 & 3 & 7 \\
6 & Apakah sarana telah mendukung implementasi k13? & 4 & 4 & 2 & 1 & 8 \\
\hline
\end{tabular}

Keterangan: TS $=$ Tidak Setuju $\quad \mathrm{S}=$ Setuju $\quad \mathrm{SS}=$ Sangat Setuju

Adapun presentase guru dan siswa di SMA Muhammadiyah 3 Jember dan SMA Negeri 2 Tanggul berdasarkan tabel diatas yaitu sebagai berikut:

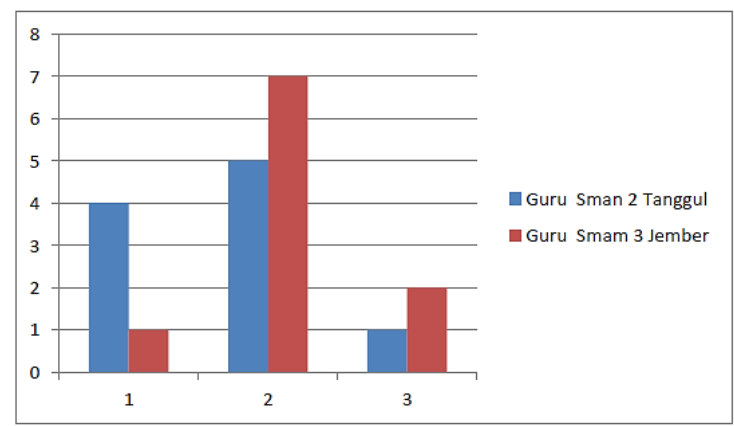

Diagram 1.1 Presentase Guru di SMA Muhammadiyah 3 Jember dan SMA Negeri 2 Tanggul

Pada presentase guru di SMA Muhammadiyah 3 Jember dan SMA Negeri 2 Tanggul dapat dilihat dari respon terhadap perubahan kurikulum di bawah ini:

\begin{tabular}{lllll}
\hline Keterangan & Sekolah & $\begin{array}{l}\text { Tidak } \\
\text { Setuju }\end{array}$ & Setuju & $\begin{array}{l}\text { Sangat } \\
\text { Setuju }\end{array}$ \\
\hline Guru & $\begin{array}{l}\text { SMAM 3 } \\
\text { Jember }\end{array}$ & 1 & 7 & 2 \\
$\begin{array}{l}\text { SMAN 2 } \\
\text { Tanggul }\end{array}$ & 4 & 5 & 1 \\
\hline
\end{tabular}

Presentase yang kedua menunjukkan adanya respon siswa terhadap keaktifan dalam proses pembelajaran atau KBM berlangsung yaitu:

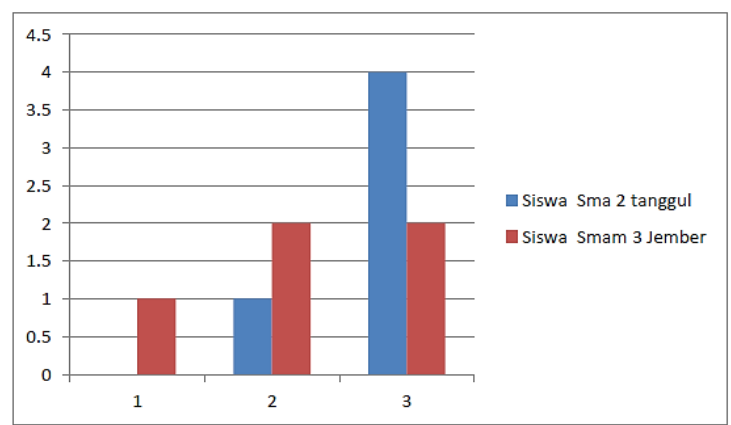

Diagram 1.1 Presentase Guru di SMA Muhammadiyah 3 Jember dan SMA Negeri 2 Tanggul

Presentase siswa yang ada di SMA Muhammadiyah 3 Jember dan SMA Negeri 2
Tanggul dapat dilihat tanggapan terhadap tingkat keaktifan siswa yaitu:

\begin{tabular}{lllll}
\hline Keterangan & Sekolah & $\begin{array}{l}\text { Tidak } \\
\text { Setuju }\end{array}$ & Setuju & $\begin{array}{l}\text { Sangat } \\
\text { Setuju }\end{array}$ \\
\hline Siswa & $\begin{array}{l}\text { SMAM 3 } \\
\text { Jember } \\
\text { SMAN 2 } \\
\text { Tanggul }\end{array}$ & 0 & 1 & 4 \\
\hline
\end{tabular}

Perubahan kurikulum 2013 diharapkan dapat memberi dampak yang lebih baik bagi pendidikan di Indonesia. Dampak tersebut didukung dari banyak faktor antara lain tenaga pengajar dan peserta didik (Ormond, 2017). Hubungan timbal balik yang diberikan peserta didik kepada pengajar dapat mengetahui respon peserta didik terhadap penyampaian materi pembelajaran yang dilakukan. Menurut Julian (2014) memaparkan tentang sebuah pengimplementasian kurikulum yang baru seorang tenaga pendidik sangat berperan penting terhadap keberhasilan proses pembelajaran. Mata pelajaran geografi merupakan mata pelajaran yang memiliki cakupan yang luas sehingga perlu adanya penataan pada mata pelajaran geografi serta yang memperhatikan keberlanjutan dan syarat materi sebagai dasar untuk langkah yang berikutnya (Nofrion, 2015). Pembelajran geografi dirasa sangat menyenangkan jika siswa tersebut dapat mengikuti materi pembelajaran dengan baik. Pada hasil belajar siswa dengan menggunakan nilai otentik dapat digunakan sebagai perbaikan proses pembelajaran yang sesuai dengan SKL (Standart Penilaian Pendidikan) (Zanna,2017). Hal tersebut juga sama dengan penuturan menurut Latief (2014) memaparkan hasil belajar merupakan sebuah proses terhadap penguasaan materi pembelajaran mencakup pengetahuan, keterampilan, dan sikap yang diperoleh setelah melakukan suatu proses pembelajaran. Pencapaian pelaksanaan kurikulum 2013 menuntut pendidik untuk selalu bersikap professional, cerdas, inovatif, dan kreatif seorang pendidik diwajibkan untuk memiliki kompetensi pendagogik, sosial dan kepribadian yang baik (Norsidi,2018).

Pada perubahan kurikulum, menurut (Mulyasa, 2013) yang berpandangan bahwa saat 
ini kita membutuhkan kurikulum yang berbasis pada kompetensi sekaligus berbasis pada karakter sehingga dapat membekali peserta didik dengan berbagai sikap dan kemampuan yang sesuai dengan perkembangan zaman dan perkembangan teknologi. Perubahan kurikulum 2013 yang memacu permasalahan seperti persiapan staf maupun guru yang dituntut untuk menguasai program teknolgi informasi, maupun di pihak siswa yang secara proses pembelajaran dituntut untuk lebih kritis dan mendominasi keaktifan di kelas. Proses pembelajaran yang dilaksanakan berbasis aktifitas dan keaktifan belajar siswa dengan menggunakan pendekatan Saintifik (ilmiah). Salah satu tantangan yang dihadapi pada masa peralihan atau pergantian merupakan sebuah keterbatasan kemampuan dan keterbatasan wawasan seorang guru dalam system penilaian (Eraslan, 2013). Pada proses kegiatan pembelajaran saintifik (mengamati, menanya, mengeksplor, mengasosiasi, mengomunikasikan atau mendemonstrasikan) pelaksanaan kurikulum 2013 bertujuan untuk mempersiapkan manusia negara Indonesia agar memiliki kemampuan hidup sebagai pribadi dan warga negara yang beriman, produktif, kreatif, inovatif, efektif, serta mampu berkontribusi pada kehidupan kemasyarakatan, berbangsa, bernegara dan peradaban dunia sehingga hal ini sama dengan pemaparan Widyastono (2014) yang menyatakan bahwa strategi pembelajaran kurikulum 2013 merupakan bentuk untuk memperbaiki kualitas pendidikan anak bangsa dalam menalar, memahami, menerapkan, sehingga mereka mampu melatih pembentukan pendidikan karakter serta mampu mengembangkan kualitas tenaga pendidik dalam membentuk sikap spritual, sosial, pengetahuan dan terampil. Pada pihak instansi yang sudah menerapkan kurikulum 2013, maka guru dituntut untuk secara profesional merancang pembelajaran afektif dan bermakna, mengorganisasikan pembelajaran, memilih pendekatan pembelajaran yang tepat, menentukan prosedur pembelajaran dan pembentukan kompetensi secara efektif serta menetapkan kriteria keberhasilan (Mulyasa, 2013).

Pemaparan menurut Mulyana (2010) menjelaskan bahwa cara guru untuk memahami peserta didik dapat berupa mengembangkan potensi atau kelebihan peserta didik sekaligus membantu kesulitan yang dihadapi peserta didik. Pengembangan potensi ini diperlukan dalam pengimplementasian kurikulum 2013 sesuai dengan pendapat Asfiati

(2016) bahwa kurikulum 2013 dikembangkan dengan landasan filosofis sebagai dasar pengembangan potensi peserta didik. Berbagai pendapat yang berkembang dengan adanya perubahan kurikulum menunjukkan bahwa guru memegang peran penting dalam perubahan kurikilum. Sebaik apapun kurikulum yang dibuat, jika guru yang menjalankan tidak memiliki kemampuan yang baik, maka kurikulum tersebut tidak akan berjalan dengan baik sehingga dalam implementasi KTSP, kesiapan sekolah mencakup kesiapan materiil dan non materiil Yusuf (2007). Kesiapan tersebut meliputi kesiapan perangkat kurikulum, sarana prasarana sekolah, kesiapan anggaran pendidikan, dan terakhir kesiapan guru.

Pencapaian di abad 21 yang melalui penerapan kurikulum 2013 ini dapat dilakukan dengan memperbaharui kualitas pembelajaran, membantu peserta didik meningkatkan dan mengembangkan partisipasi, mendorong kerjasama dan komunikasi serta membudayakan keterampilan berpikir kreatif sehingga pembelajaran dapat berpusat pada kegiatan peserta didik dengan bimbingan dan pengawasan dari guru (Zubaidah, 2016). Pada metode pembelajaran serta media pembelajaran yang mewadai maka pencapaian dalam penerapan kurikulum 2013 dapat diindikatorkan akan berjalan sesuai dengan harapan kurikulum 2013 tersebut. Penyiapan guru menyangkut mindset dan kesiapan dalam menghadapi perkembangan kurikulum harus benar benar diperhatikan (Kristiantari, 2015). Guru yang berperan sebagai fasilitator dalam proses pembelajaran memiliki daya dukungan untuk peserta didik yang berperan aktif dalam kelas ketika dilakukan diskusi ataupun dihadapkan terhadap penyelesaian permasalahan terkait materi geografi.

Guru yang profesional akan senantiasa meningkatkan kualitas diri dan akan senantiasa dalam memperbarui pengetahuan secara bertahap (Fahdini, 2014) sehingga guru akan mengusahakan untuk mendapatkan pengetahuan atau pemahaman lebih mengenai model, metode yang akan dilakukan pada saat kegiatan belajar mengajar, agar dapat membuat siswa

lebih aktif. Keaktifan belajar siswa merupakan unsur penting didalam pembelajaran. Menurut Sudjana (2009) 
menyatakan bahwa keaktifan merupakan kondisi siswa dapat berperan aktif dalam pembelajaran seperti bertanya kepada guru, berdiskusi di dalam kelompok dengan siswa lain, mampu menemukan dan memecahkan masalah. Pentingnya keaktifan belajar tersebut didukung dalam pernyataan yang disampaikan Slameto (2015) bahwa terdapat faktor- faktor yang mempengaruhi hasil belajar siswa, baik dari dalam diri maupun luar siswa. Pada penentuan sejauh mana tingkat keaktifan belajar siswa maka dapat dilihat dari ciri- ciri yang tampak dalam pembelajaran yaitu bertindak sesuatu agar dapat mengerti materi pelajaran, menemukan cara sendiri dalam memahami materi, mencoba mengerjakan tugas- tugas baik secara kelompok maupun individu serta mampu menyampaikan hasil dalam bentuk lisan maupun tertulis. Permasalahan yang terdapat pada kurikulum 2013 pertama diawali dengan belum adanya kesiapan guru yang ada dilpang dalam penerapan kurikulum 2013 yang meliputi : a. guru diharapkan menguasai banyak materi terutama pada bidang sosial, b. belum adanya kesiapan guru untuk mencerna hakikat kurikulum 2013, c. kurang adanya pengetahuan guru terhadap teknologi terutama untuk tenaga pengajar yang telah senior, d. praktik lapang hanya meniru tanpa ada perubahan (Ruja (2017).

Pada hasil tabel dapat diindikatorkan bahwa respon siswa terhadap mata pelajaran geografi dan sikap guru terhadap perubahan kurikulum 2013. Pada penelitian Damayanti (2018) dijelaskan bahwa penyesuaian materi yang terdapat pada mata pelajara geografi pada kurikulum 2013 tidaklah menuntut sesuai tahapan berfikir siswa serta jangkauan yang terlalu luas. Respon yang baik pada siswa dapat ditunjukkan dari seberapa keingintahuannya terhadap mata pelajaran tersebut yaitu dari 18 pertanyaan yang diajukan oleh peneliti 4 dari 5 siswa yang terdapat pada SMA Negeri 2 Tanggul menunjukkan sikap aktif terhadap pembelajaran yang dilakukan didalam kelas ataupun diluar kelas. Keaktifan tersebut

ditunjukkan dari sikap mereka yang mempelajari terlebih dahulu materi yang akan diajarkan di kelas, selain itu mereka mencoba mencari sumber lain selain buku tekas yang ada. Guru SMA Negeri 2 Tanggul merasa masih kurang maksimal dalam menjalankan perubahan kurikulum yang ada namun, peserta didik yang ada pada SMA negeri 2 Tnggul menujukkan sikap positif terhadap perubahan kurikulum
2013. Hal ini sejalan dengan pernyataan yang dipaparkan oleh Hermawan (2019) yang menyatakan bahwa pada pengimplementasian kurikulum 2013 masih terdapat kegagapan dalam hal penerapannya. Hambatan yang ada pada pengimplementasian di SMA Negeri 2 Tanggul terdapat pada faktor tenaga pengajar.

Di SMA Muhammadiyah 3 Jember telah menerapkan kurikulum 2013 dan mengakui di sekolah ini menjadi sekolah perintis dari pengimplimentasian kurikulum 2013. Luqman (2019) selaku kepala sekolah di SMA Muhammadiyah 3 Jember memaparkan bahwa:

"Sekolah Muhammadiyah ini telah menggunakan kurikulum 2013 sejak kurikulum 2013 pertama kali digalakkan. Sekolah ini telah memperbaiki fasilitasfasilitas yang ada sehingga kurikulum 2013 dapat dilaksanakan dengan baik. Kurikulum 2013 dirasa membuat sekolah SMA Muhammadiyah 3 menjadi lebih baik hal tersebut terbukti dari fasilitas internet yang kini semakin membaik, media pembelajaran yang diterapkan pada peserta didik kini semakin beragam dan lengkap. Pihak sekolah telah melakukan usaha semaksimal mungkin untuk menumbuhkan pendidikan karakter pada siswa namun itu semua tergantung pada siswa itu sendiri serta lingkup pergaulan mereka."

Penanaman pendidikan karakter guna pengimplementasian kurikulum 2013 yang terdapat pada SMA Muhammadiyah 3 dirasa sudah cukup banyak usaha untuk mengubah karakter pesera didik menjadi lebih baik. Usaha pada pengimplementasian kurikulum 2013 terhadap karakter siswa antara lain dengan diadakannya sholat dhuhur dan sholat asar berjamaah disekolah. Semua staf karyawan ikut mendukung program ini dengan mengkitunya dan membujuk siswa untuk mengikuti kegiatan tersebut. Upaya yang dilakukan oleh sekolah guna pengoptimalkan kegiatan tersebut antara lain dengan menyisir setiap sudut sekolah hingga tidak ada siswa yang tersisa lagi. Selain pendidikan karakter tersebut, pada mata pelajaran geografi ibu Anik (2019) selaku guru geografi memaparkan:

\footnotetext{
"Mata pelajaran geografi merupakan mata pelajaran yang menyenangkan. Setiap materi pembelajaran yang mengharuskan siswa terjun langsung,
} 
saya memberikan tugas kepada mereka untuk terjun langsung ke lapangan dan hasil tersebut dikemas dalam bentuk film pendek. Film pendek tersebut merupakan contoh output dari kurikulum 2013 yang mengharuskan tenaga pengajar ataupun peserta didik untuk tidak gaptek. Saya meminta mereka untuk mengajari saya bagaimana cara pembuatan video agar menarik sehingga saya tidak terlalu gaptek dalam teknologi. Perubahan kurikulum 2013 ini dirasa memberi dampak positif bagi saya, namun untuk siswa yang kurang aktif di kelas, harus mengeluarkan tenaga yang berlebih."

Kemampuan berfikir kritis siswa dapat dilatih dengan menerapkan model pembelajaran Project Based Learning (Hayati, 2016). Model pembelajaran ini juga diterapkan pada SMA Muhammadiyah 3 Jember terutama pada mata pelajaran geografi. Siswa terjun langsung kelapangan guna mendapatkan solusi terhadap permaslahan yang ada. Pendapat diatas relevan dengan penelitian Wijayati (2016) permasalahan yang didapat pada penerapan kurikulum 2013 oleh tenaga pengajar bidang ilmu sosial yaitu tentang penerapan pendekatan saintifik. Pendekatan ini menuntut pendidik untuk membuat para peserta didik memiliki sikap yang aktif dalam sebuah proses pembelajaran. Pada tabel diatas ditunjukkan bahwa guru pada SMA Muhammadiyah 3 Jember telah siap dengan adanya perubahan kurikulum KTSP 2006 ke Kurikulum 2013 (K-13). Kesiapan peserta didik terhadap perubahan yang ada dirasa kurang maksimum dan keaktifan siswa dapat dilihat dari respon siswa yang menyatakan bahwa mereka terkadang mencari tahu materi pembelajaran serta bertanya kepada guru yang bersangkutan. Pihak sekolah telah megadakan pembekalan secara berkala untuk para guru yang ada pada SMA Muhammadiyah 3 Jember namun kendala ini bersumber dari siswa yang kurang adanya partisipasi terhadap diberlakukannya kurikulum 2013. Antara guru dengan peserta didik harus memiliki respon yang positif terhadap diberlakukannya kurikulum 2013. Hal ini dikarenakan jika hanya satu pihak yang mendukung, maka kurikulum 2013 tidak dapat terlaksana dengan baik, namun jika semua pihak ikut berperan aktif maka pengimplementasian kurikulum pada sekolah tersebut data berjalan dengan baik.
Guru disetiap sekolah dalam mengimplementasikan kurikulum K13 dapat dilihat dari kesiapan guru menyusun RPP, kegiatan pembelajaran dan penilaian pada siswa yang diajarkan (Kartika, 2017). Implementasi kurikulum 2013 di SMAN 2 Tanggul dan SMA Muhammadiyah 3 Jember pada awalnya mengalami beberapa kesulitan, kesulitan pada awal penerapannya lebih kepada sarana dan prasarana yang ada. diterapkan kedala terkait sarana dan prasarana telah teratasi, hal ini berdasarkan hasil survey bahwasannya kedua sekolah telah memiliki sarana dan prasarana yang memadai. Silabus pada kurikulum 2013 telah ditentukan oleh pemerintah dan telah menjadi acuan dalam pelaksanan kurikulum 2013. Menurut guru di SMAN 2 Tanggul penetapan silabus yang ada memiliki kesesuaian dengan karakter siswa di SMAN 2 Tanggul. Jejak pendapat guru di SMA Muhammadiyah 3 Jember sendiri $50 \%$ ada yang ragu-ragu dan ada yang setuju, bahwa silabus yang ditetapkan telah sesuai dengan karakter siswa.

Pengaruh adanya kompetensi pedagogik dalam kesiapan seorang guru sangat penting dalam mengimplementasikan kurikulum 2013 di setiap sekolah agar diterapkan dengan sesuai kaidahnya (Roni. 2017). Penerapan kurikulum 2013 diharapkan siswa dapat memiliki karakter yang baik, memiliki mental kreatif dan inovatif (Jupriadi, 2017). Hal ini di setujui oleh mayoritas guru baik di SMAN 2 Tanggul dan SMA Muhammadiyah 3 Jember, bahwa penerapan kurikulum 2013 dapat meningkatkan karakter, kreativitas, dan inovatif siswa. Penerapan kurikulum 2013 juga diharapkan dapat meningkatkan pola pikir siswa yang kritis sehingga pernyataan ini di setujui oleh mayoritas kedua sekolah berdasarkan hasil survey, bahwa penerapan kurikulum 2013 telah merubah siswa menjadi pribadi yang kritis. Penerapan kurikulum 2013 terdapat pengintegrasian pembelajaran baik IPA dan IPS dalam mata pembelajaran bahasa Indonesia, guru di SMA Muhammadiyah 3 Jember sendiri mayoritas tidak setuju, sedangkan di SMAN 2 Tanggul 50:50 dimana ada yang tidak setuju dan ada yang ragu-ragu. Guru di SMAN 2 Tanggul dan SMA Muhammadiyah 3 Jember sependapat bahwasanya mudah mengimplementasikan kurikulum 2013. Selain itu, buku yang merupakan fasilitas pendukung dalam penerapan kurikulum 2013 di SMA Muhammadiyah 3 Jember telah mewadai dan 
jumlahnya telah mencukupi kebutuhan peserta didik, sedangkan di SMAN 2 Tanggul buku yang tersedia masih belum mencukupi kebutuan siswa.

Kurikulum 2013 sendiri dirancang dalam pembelajarannya yang terkait satu dengan yang lain dan memiliki kompentesi dasar yang terikat oleh kompetensi inti. Menurut pandangan guru di SMAN 2 Tanggul dan SMA Muhammadiyah 3 Jember, rancangan tersebut sangat baik bagi pembelajaran karakter siswa. Mayoritas guru di SMAN 2 Tanggul dan SMA Muhammadiyah 3 Jember dengan berbagai mata pelajaran menyetujui bahwasanya mata pelajaran yang diajarkan dapat dikaitkan dengan kompetensi inti baik KI-1, KI-2, KI-3, dan KI-4. Guru di SMAN 2 Tanggul menurut hasil survey penerapan siswa sebagai subjek dalam proses pembelajaran ada yang tidak setuju jika penerapan tersebut dilakukan dan ada yang ragu-ragu, perbandingan dari kedua jawaban ini 50:50. Sedangkan di SMA Muhammadiyah 3 Jember mayoritas guru masih ragu-ragu penerapan siswa sebagai subjek sulit untuk diterapkan.

Pada kurikulum 2013 dirancang semua mata pembelajaran diajarkan menggunakan pendekatan saintifik, tematik terpadu, dan menekankan siswa untuk mengamati, menanya, mencoba dan menalar (Selvira, 2016). Menurut hasil survey baik guru SMAN 2 Tanggul dan SMA Muhammadiyah 3 Jember mayoritas setuju bahwa rancangan tersebut cocok untuk mata pelajaran yang diajarkan. Mayoritas guru baik di SMAN 2 Tanggul dan SMA Muhammadiyah 3 Jember sependapat masih ragu-ragu bahwa mata pelajaran yang diajarakan memiliki pendekatan yang berbeda dengan pendekatan yang telah dirancang pada kurikulum 2013. Guru di SMAN 2 Tanggul dan SMA Muhammadiyah 3 Jember juga sependapat bahwasanya mata pelajaran yang diajarkan telah mendukung kompetensi sikap, keterampilan dan dan pengetahuan. Materi pokok yang telah ditentukan pada silabus di kurikulum 2013 telah sesuai dengan karakter siswa di SMA Muhammadiyah 3 Jember, sedangkan di SMAN 2 Tanggul pilihan jawaban guru berbanding 50:50 antara ragu-ragu dan setuju jika materi pokok di silabus kurikulum 2013 telah sesuai dengan karakter siswa. Guru di SMAN 2 Tanggul dan SMA Muhammadiyah 3 Jember sependapat bahwasannya model pembelajaran yang ditekannkan kurikulum 2013 telah sesuai dengan karakter siswa di masing-masing sekolah dan mata pelajaran yang di ajarkan (Rini, 2014).

Guru di SMAN 2 Tanggul dan SMA Muhammadiyah 3 Jember sependapat mengenai standar penilaian yang diterapkan pada kurikulum 2013 sangat baik untuk diimplementasikan. Guru di SMA Muhammadiyah 3 Jember meyakini standart penilaian memang baik diterapkan, namun mayoritas guru juga setuju bahwasanya standart penilaian kurikulum 2013 sangat rumit dan tidak efektif dalam penerapannya, sedangkan guru di SMAN 2 Tanggul berpendapat bahwa standart penilaian kurikulum 2013 bisa jadi rumit dan kurang efektif. Siswa di SMAN 2 Tanggul sudah beradaptasi dan menyesuaikan dengan adanya kurikulum 2013 tetapi tidak dengan guru yang masih belum siap menerapkannya. Sedangkan di SMA Muhammadiyah 3 Jember berbanding sebaliknya yaitu guru lebih siap daripada siswanya dan siswa masih belum siap dengan adanya kurikulum 2013.

\section{KESIMPULAN}

Pembelajaran kurikulum 2013 merupakan bentuk untuk memperbaiki kualitas pendidikan anak bangsa dalam menalar, memahami, menerapkan, sehingga mereka mampu melatih pembentukan pendidikan karakter serta mampu mengembangkan kualitas tenaga pendidik dalam membentuk sikap spritual, sosial, pengetahuan dan trampil. Perubahan kurikulum 2013 yang memacu permasalahan seperti persiapan staf maupun guru yang dituntut untuk menguasai program teknolgi informasi (TI), maupun di pihak siswa yang secara proses pembelajaran dituntut untuk lebih kritis dan mendominasi keaktifan di kelas. Guru di SMA Muhammadiyah 3 Jember meyakini standart penilaian memang baik diterapkan, namun mayoritas guru juga setuju bahwasanya standart penilaian kurikulum 2013 sangat rumit dan tidak efektif dalam penerapannya, sedangkan guru di SMAN 2 Tanggul berpendapat bahwa standart penilaian kurikulum 2013 bisa jadi rumit dan kurang efektif.

Siswa di SMAN 2 Tanggul sudah beradaptasi dan menyesuaikan dengan adanya kurikulum 2013 tetapi tidak dengan guru yang masih belum siap menerapkannya. Sedangkan di SMA Muhammadiyah 3 Jember berbanding 
sebaliknya yaitu guru lebih siap daripada siswanya dan siswa masih belum siap dengan adanya kurikulum 2013.

\section{DAFTAR PUSTAKA}

Afandi, R. 2013. Implementasi Kurikulum 2013 Dalam Mempersiapkan Sumber Daya Manusia Indonesia Menghadapi "Masyarakat Ekonomi Asean" (Asean Economic Community) Pada 2015. In Prosiding Seminar Nasional Pendidikan: Tema "Implementasi Kurikulum.

Agustin Pramesti, Kartika. 2017. Kesiapan Guru Ekonomi Dalam Implementasi Kurikulum 2013 Di Sekolah Menengah Atas Neheri Kota Yogyakarta. Jurnal Pendidikan Dan Ekonomi, Volume 6 Nomor 6, Hal: 623-634

Alim, Roni. 2017. Pegaruh kompetensi padagogik dan kesiapan guru terhadap implementasi kurikulum 2013. Jurnal Geografi, Volume 15 Nomor 1, Hal: 18-29 Anik. 2018. Implementasi Kurikulum 2013 pada SMA Muhammadiyah 3 Jember, di SMA Muhammadiyah 3 Jember.

Asfiati. 2016. Pendekatan Humanis dalam Pengembangan Kurikulum. Medan: Perdana Publishing.

Damayanti, Defrianti Kartika Eka. 2018. Implementasi Kurikulum 2013 Pada Mata Pelajaran Geografi Di Sma Negeri 4 Watampone. LaGeografia, Volume 17 Nomor 1, Hal: 30-44.

E, Mulyasa. 2013. Pengembangan dan Implementasi Kurikulum 2013. Bandung: Remaja Rosdakarya.

Eraslan, A. 2013. Teachers' Reflections on the Implementation of the New Elementary School Mathematics Curriculum in Turkey. Hacettepe Üniversitesi Eğitim Fakültesi Dergisi, Volume 28 Nomor 2, Hal: 152165.

Fahdini, R., Mulyadi, E., Suhandani, D., \& Julia, J. 2014. Identifikasi Kompetensi Guru sebagai Cerminan Profesionalisme Tenaga Pendidik di Kabupaten Sumedang. Mimbar Sekolah Dasar, Volume 1 Nomor 1, Hal: 33-42.

Gunawan, B. I. 2017. Perbandingan implementasi kurikulum tingkat satuan pendidikan (KTSP) dan kurikulum 2013 di SMAN 1 Sinjai Utara. Jurnal Mirai
Management, Volume 1 Nomor 1, Hal: 19.

Hayati, Wahyu Islamul, Sugeng Utaya, and I. Komang Astina. 2016. Efektivitas Student Worksheet Berbasis Project Based Learning dalam Menumbuhkan Kemampuan Berpikir Kritis Siswa pada Mata Pelajaran Geografi. Jurnal Pendidikan: Teori, Penelitian, dan Pengembangan, Volume 1 Nomor 3, Hal: 468-474.

Hermawan, Arief Yulianto, and Sriyanto Sriyanto. 2019. Implementasi Kurikulum 2013 Pada Mata Pelajaran Geografi di Sma Negeri SeKabupaten Pemalang. Edu Geography, Volume 7 Nomor 2, Hal: 142150.

Julian Pratama, A. R. D. Y. 2014. Kesiapan Guru Sma Dalam Implementasi TIK Pada Mata Pelajaran Geografi Untuk Menunjang Kurikulum 2013 Di Kabupaten Sidoarjo. Swara Bhumi, Volume 3 Nomor 3

Jupriadi. 2017. Analisis dan implementasi penerapan kurikulum 2013 terhadap haya mengajar guru di sekolah. Jurnal ilmiah pendidikan, Volume 4 Nomor 3, Hal: 217226

Kristiantari, Rini. 2014. Analisis Kesiapan Guru Sekolah Dasar Dalam Mengimplementasikan Pembelajaran Tematik Integrative Menyongsong Kurikulum 2013. Jurnal Pendidikan Indonesia, Volume 3 Nomor 2, Hal: 460469.

Latief, Hilman. 2014. Pengaruh Pembelajaran Kontekstual Terhadap Hasil Belajar (Studi Eksperimen Pada Mata Pelajaran Geografi Kelas Vii Di Smpn 4 Padalarang). Jurnal Geografi Gea, Volume 14 Nomor 2.

Luqman. 2019. Implementasi Kurikulum 2013 Pada SMA Muhammadiyah 3 Jember, Di SMA Muhammadiyah 3 Jember.

Machali I, 2014. Kebijakan Perubahan Kurikulum 2013 dalam Menyongsong Indonesia Emas Tahun 2045. Fakultas Ilmu Tarbiyah dan Keguruan UIN Sunan Kalijaga Yogyakarta.

Margono. 2015. Pembelajaran Menulis Teks Laporan Hasil Observasi Berbasis Kearifan Lokal Pada Siswa Kelas VII A4 SMP Negeri 1 Singaraja. Jurnal Pendidikan Bahasan dan Sastra Indonesia, 
Volume 3 Nomor 1. Universitas Pendidikan Ganesha.

Mulyana A.Z. 2010. Rahasia Menjadi Guru Hebat (Memotivasi Diri Menjadi Guru Luar Biasa). Jakarta: Grasindo.

Mulyasa, E. 2013. Problematika K13 Dalam Pembelajaran PAI. Journal of Islamic Religious Educatin, Volume 1 Nomor 2. Institut Agama Islam Negeri Kediri.

Nofrion, Nofrion. 2018. Penguatan Kurikulum dan Pembelajaran Geografi.

Norsidi, Norsidi, And Paiman Paiman. 2018. Analisis Kompetensi Pedagogik Guru Mata Pelajaran Geografi Sekolah Menengah Atas (SMA) Sebagai Pelaksana Kurikulum 2013 Di Kabupaten Ketapang. Sosial Horizon: Jurnal Pendidikan Sosial, Volume 5 Nomor 2, Hal: 202-216.

Ormond, B.M. 2017. Curriculum decisions-the challenges of teacher autonomy over knowledge selection for history. Journal of Curriculum Studies, Volume 49 Nomor 5 , Hal: 599-619.

Ruja, I. Nyoman. 2017. Survey Permasalahan Implementasi Kurikulum Nasional 2013 Mata Pelajaran Ilmu Pengetahuan Sosial Sekolah Menengah Pertama Di Jawa Timur. Sejarah Dan Budaya: Jurnal Sejarah, Budaya, Dan Pengajarannya, Volume 9 Nomor 2, Hal: 193-199.

Selvira, Mega Paut. 2016. Penerapan Pendekatan Saintifik Pada Siswa Kelas 4 Di SDN Pujokusuman 1 Jogyakarta. Jurnal Pendiidkan Guru SD, Volume 6 Nomor 5, Hal: 1-12

Slameto. 2015. Upaya Meningkatkan Keaktifan dan Prestasi Belajar Matematika Siswa dengan Menggunakan Pembelajaran Kooperatif Tipe Two Stay Two Stray (TSTS). Jurnal Ilmiah Edukasi Matematika, Volume 1 Nomor 1. Hal 7- 21.

Sudjana, Nana. 2009. Penilain Hasil Proses Belajar Mengajar. Bandung: Remaja Rosdakarya.

Sutoyo, Anwar. 2009. Pemahaman Individu. Semarang : CV. Widya Karya. Tatang, M. A. 2011. Manajemen Pendidikan.

UUSPN Nomor 20 Tahun 2003 BAB IX, Pasal 35 , ayat 2 , dan juga lihat pada penjelsan pasal demi pasal.

Widyastono. 2014. Kesiapan Guru dalam Implementasi Kurikulum 2013. Jurnal Info Singkat Kesejahteraan Sosial DPR RI. VI, Volume 15. Hal 9-12.
Wijayati, E. C., Degeng, I. N. S., \& Sumarmi, S. 2016. Kesulitan-Kesulitan dalam Implementasi Kurikulum Mata Pelajaran IPS SMP. Jurnal Pendidikan: Teori, Penelitian, dan Pengembangan, Volume 1 Nomor 11, Hal: 2241-2247.

Wijayati, Eni Cahya, I. Nyoman Sudana Degeng, And Sumarmi Sumarmi. 2016. Kesulitan-Kesulitan Dalam Implementasi Kurikulum Mata Pelajaran IPS SMP. Jurnal Pendidikan: Teori, Penelitian, Dan Pengembangan, Volume 1 Nomor 11, Hal: 2241-2247.

Yusuf A. 2007. Kesiapan Sekolah dalam Mengimplementasikan Kurikulum Tingkat Satuan Pendidikan (KTSP). Lembaran Ilmu Kependidikan, Volume 36 Nomor 2, Hal: 85-95.

Zanna, Nur, And Marlinang Sitompul. 2017. Implementasi Kurikulum 2013 Pada Pembelajaran Geografi Berdasarkan Standar Proses. Jupiis: Jurnal Pendidikan Ilmu-Ilmu Sosial, Volume 9 Nomor 2, Hal: 166-170.

Zubaidah, S. 2016. Keterampilan Abad ke-21: Keterampilan yang Diajarkan melalui Pembelajaran. Journal of Teachers Work, Volume 4 Nomor 2. Hal 89-98. STKIP Persada Khatulistiwa Kalimantan Barat. 